DOI: $10.22616 /$ j.balticsurveying.2018.013

\title{
TENDENCIES OF DEVELOPMENT OF LOCAL GEODETIC NETWORK IN RIGA CITY
}

\author{
Armands Celms ${ }^{1}$, Velta Parsova1, Ilona Reke ${ }^{1}$, Janis Akmentins ${ }^{1,2}$ \\ ${ }^{1}$ Latvia University of Life Sciences and Technologies \\ ${ }^{2}$ Riga City Construction Board, Construction Control Department
}

\begin{abstract}
Local geodetic network is very important in harmonic development of city territory. On the base of the local geodetic network, cadastral and topographic surveying works, engineering geodetic works and executive measurements of newly built buildings and engineering networks are carried out. In the territory of Riga, the local geodetic network was started to create in 1880 , and in the course of time, as the city expanded, necessity to have wider reference network emerged. In 2005, in the territory of Latvia, network of continuously working base stations LatPos was launched, which ensured completely new trends in execution of measurements and accuracy reached. One year later, base station network EUPOS-RIGA was launched in the territory of Riga. It can be regarded as consistent part of Riga local geodetic network. The purpose of the research was to state, what are differences between historically used coordinates of points of the local geodetic network, and coordinates that are determined by use of real time corrections of LatPos and EUPOS-RIGA base station network. Measurements were made in the territory of Riga in period from December 2016 until April 2017. In the framework of the research, 61 point of the local geodetic network was inspected and in 38 cases GNSS observations in RTK mode were completed. In the research, catalogues of coordinates of polygonometry points of sixties and eighties were used in order to compare what differences of coordinates existed historically. The main conclusion drawn during the research - historical points of the local geodetic network shall not be used for surveying works of any kind before improvement of them and before they comply with requirements of normative acts.
\end{abstract}

Key words: geodesy, LatPos, EUPOS-RIGA, network, survey.

\section{Introduction}

In 1880 - 1882, in the territory of Riga City, according to order of Building Board of Riga City, the first triangulation network was created. This triangulation network can be considered as beginning of contemporary local geodetic network in the territory of Riga City, which served as a base for further works of establishment of the local geodetic network (Silabriedis, 2010). Till 1990, in the territory of Riga, six polygonometry network establishing works and eight leveling network establishing works can be distinguished. All above-mentioned works of establishing of the local geodetic network were carried out by such methods and technical base, which do not ensure accuracy complying with contemporary requirements (Biezak uzdotie jautajumi..., 2018). As usage of global navigation satellite system (GNSS) was started in geodesy, mismatches between historically calculated coordinates of points of the local geodetic network and coordinates determined by use of GNSS technologies emerged. Also change of height system introduced its corrections (Balodis et al., 2016). This difference of coordinates creates problems in determination, inspection and restoration of land boundaries, in production of topographic plans and performance of engineering geodetic works.

The purpose of the research is to clarify differences of coordinates of local geodetic network determined in different periods, to determine their coordinates by use of contemporary technologies.

\section{Methodology of research and materials}

There are historical catalogues of coordinates and heights of Riga polygonometry network used:

1. catalogue of coordinates and heights of polygonometry network of 1963 , volume 16 ,

2. catalogue of coordinates and heights of polygonometry points of class 4 of 1985, object Riga-1,

3. catalogue of coordinates and heights of polygonometry points of class 4 of 1987, object Riga-2,

4. catalogue of coordinates and heights of polygonometry points of class 4 of 1989, object Riga-3.

In the catalogue of 1963, coordinates and heights of polygonometry points of class 1, 2, and 3 with higher accuracy can be found, which are obtained in the period 1958-1962. Coordinates are given in the coordinate system of 1942 , in $3^{\circ}$ zone of Gauss projection, mean meridian - $24^{\circ}$ from Greenwich. 
Heights are given in the Baltic height system. Works of establishment of polygonometry network were performed by Leningrad City Planning Institute "Lengiprogor". For measurement of angles, theodolites of high precision were used (Table 1).

Table 1

Characteristics of theodolites used

\begin{tabular}{|c|c|c|c|c|c|c|c|c|c|}
\hline \multirow{2}{*}{$\begin{array}{c}\text { Type of } \\
\text { instrument, } \\
\text { producer }\end{array}$} & \multicolumn{3}{|c|}{ Main spyglass } & \multicolumn{2}{|c|}{ Diameter of arc, mm } & \multicolumn{2}{|c|}{$\begin{array}{c}\text { Value of marking of optical } \\
\text { micrometer }\end{array}$} & \multicolumn{2}{|c|}{ Value of marking of level } \\
\hline & \begin{tabular}{|c|} 
Focal \\
length, \\
mm \\
\end{tabular} & \begin{tabular}{|c|} 
Diameter \\
of \\
objective
\end{tabular} & $\begin{array}{l}\text { Magni- } \\
\text { fication }\end{array}$ & Horizontal & Verticals & $\begin{array}{c}\text { Horizontal } \\
\text { arc }\end{array}$ & $\begin{array}{l}\text { Vertical } \\
\text { arc }\end{array}$ & $\begin{array}{l}\text { Horizontal } \\
\text { arc }\end{array}$ & $\begin{array}{l}\text { Vertical } \\
\text { arc }\end{array}$ \\
\hline \begin{tabular}{|l|} 
Big Wild, \\
Nr. 5227 \\
\end{tabular} & 350 & 60 & 30 & 140 & 95 & $0.2^{\prime \prime}$ & $0.2^{\prime \prime}$ & $6^{\prime \prime}$ & $12^{\prime \prime}$ \\
\hline $\begin{array}{l}\text { Little Wild, } \\
\text { Nr. } 3848\end{array}$ & & 40 & 28.4 & 90 & 50 & $1^{\prime \prime}$ & $1^{\prime \prime}$ & $20^{\prime \prime}$ & - \\
\hline OTC-2A & & 40 & 28.4 & 85.9 & 75.8 & $2^{\prime \prime}$ & $2^{\prime \prime}$ & $16^{\prime \prime}$ & $19^{\prime \prime}$ \\
\hline ТБ-1 & & 40 & 28 & 85.9 & 75.8 & $1^{\prime \prime}$ & $1^{\prime \prime}$ & $16^{\prime \prime}$ & $16^{\prime \prime}$ \\
\hline
\end{tabular}

The local geodetic network consists of traverses.

Mean square error of angles in the whole network was calculated according to formula:

$$
m_{\beta}=\sqrt{\frac{\left[\frac{f_{\beta}^{2}}{n}\right]}{N-K}}
$$

Where $f_{\beta}$ denotes angular deviation of traverses,

$n$ denotes amount of measured angles in traverse,

$\mathrm{N}$ denotes number of traverses,

$\mathrm{K}$ denotes number of nod points in the network.

Mean square error of measured angles was within interval from $\pm 2.9^{\prime \prime}$ to $\pm 8.9^{\prime \prime}$, depending on the category of polygonometry traverse. Edge lengths of polygonometry traverses were measured by use of baseline measurement device БП-3 with three $24 \mathrm{~m}$ long sets of wires: one of steel and two of invar. Error of locations of polygonometry points in relation to used triangulation points was in interval from $\pm 32 \mathrm{~mm}$ to $\pm 118 \mathrm{~mm}$.

In the next poligonometry network surveying works, theodolites of similar accuracy were used for measurement of angles, but distances were measured by use of light rangefinder 2CM2, which ensured mean square error of measurement $\pm 2 \mathrm{~cm}$.

In catalogue "Riga-1" of 1985, coordinates and heights, which were determined in period 1982-1984, can be found. Coordinates are given in Riga local coordinate system and heights - in Baltic height system. Works were performed by Latvian geodetic and topographic expedition "Sojuzmarkstrest".

In catalogue "Riga-2" of 1987, coordinates and heights, which were determined in period 1983-1986, can be found. Coordinates are given in Riga local coordinate system and heights - in Baltic height system. Works were performed by Latvian geodetic and topographic expedition "Sojuzmarkstrest".

In catalogue "Riga-3" of 1989, coordinates and heights, which were determined in period 1985-1987, can be found. Coordinates are given in Riga local coordinate system and heights - in Baltic height system. Works were performed by Latvian Geodetic Centre "Latvgeokarta".

In the framework of the research, measurements were performed by use of GNSS receiver Leica GS 14 , with real time corrections in order to determine coordinates of polygonometry points in Latvian geodetic coordinate system of 1992 (LKS-92) and heights in Latvian normal height system in epoch 2000,5 (LAS-2000,5). Cordinates and heights of polygonometry points selected for the research were determined by use of GNSS base station networks LatPos and EUPOS-RIGA, in cases, when it was possible.

As we can see, in different periods, different coordinate and height systems were used. In order to compare coordinates of 1942 and coordinates determined in Riga local system, simple transition from 
coordinate system of 1942 to Riga local coordinate system according to following formulas shall be performed:

$$
\begin{gathered}
X_{R V}=X_{1942}-6320000.000 \\
Y_{R V}=Y_{1942}+4000.000
\end{gathered}
$$

Where $\mathrm{X}_{\mathrm{RV}}$ denotes $\mathrm{X}$ coordinate in Riga local coordinate system,

$\mathrm{X}_{1942}$ denotes X coordinate coordinate system of 1942,

$\mathrm{Y}_{\mathrm{RV}}$ denotes $\mathrm{Y}$ coordinate in Riga local coordinate system,

$\mathrm{Y}_{1942}$ denotes $\mathrm{Y}$ coordinate coordinate system of 1942.

In order to transform coordinates of points of Riga local coordinate system to LKS 92TM system, coordinate transformation program elaborated of National Surveying Centre of State Land Service in 1996 - 1998, which is publicly available (Transformacijas programmas, 2018).

Riga continuously develops, and changes. Active construction takes place in the territory of city, as a result, Riga local geodetic network, which is built more than century ago, also experiences changes. In period 2012-2013, City Development Department of Riga City Council carried out inspection of the local geodetic network. In total, 4712 points of the local geodetic network were inspected and it was found out that somewhat more than half are preserved in normal condition (see Fig. 1.).

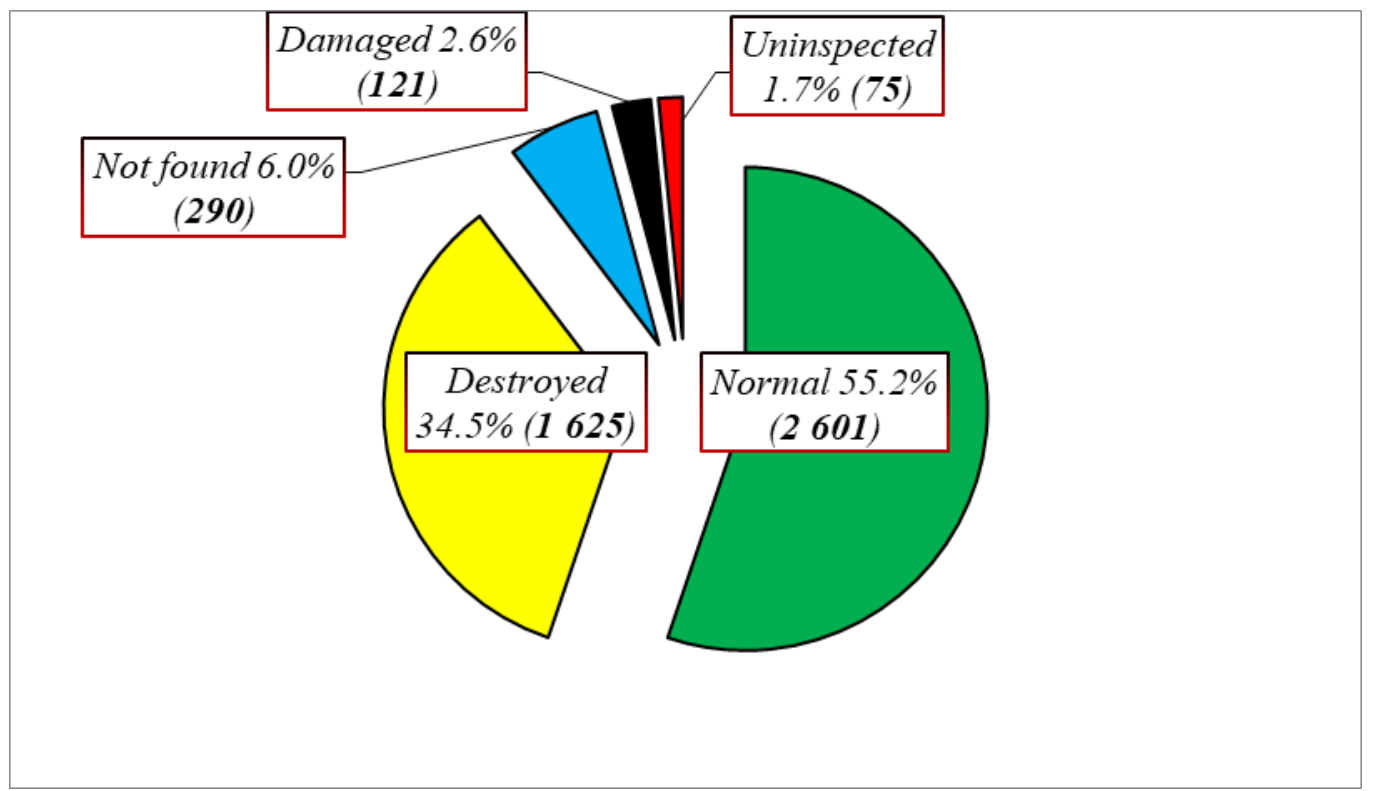

Fig. 1. Results of local geodetic network inspection according to The City Development Department of Riga City Council.

After the inspection of the local network, in the period 2012-2015, Descriptions of improvement of the local geodetic network of Riga City for following neighborhoods of Riga were compiled: Vecriga (2012), Skanste-Brasa (2013), Tornakalns-Agenskalns (2013), Mezaparks (2014), Vecaki (2014), Bergi (2015), Kipsala (2015). The aims of the improvement of the local geodetic network are to ensure compliance of geodetic reference points existing in the local network with requirements of accuracy of Regulations of Cabinet of Ministers of 24 July, 2012 No. 497 "Regulations of Local Geodetic Network" and they could be used for performance of geodetic works. Points of local geodetic networks are linked to state geodetic reference network with accuracy 3-6 cm, heights are determined with standard deviation to $1 \mathrm{~cm}$, coordinates - to $2 \mathrm{~cm}$ (Vieteja geodeziska tikla..., 2012). Improvement works include establishing and measuring of new geodetic points and preparation of improvement report, where methodology of performance of measurements, measurement data and results are summarized. Territories with densely populated build-up area, areas of new development and build-up areas with dense high vegetation are considered as prioritary territories. It is foreseen to improve the local gedetic network only in those territories of Riga, where performance of 
measurements by use of GNSS technologies is encumbered. During the execution of the research, improvement works of 248 Riga local geodetic network points in center of Riga and Grizinkalns were done (Vietejais geodeziskais tikls, 2018).

Despite the fact that Latvia is relatively small state with small population, services of several GNSS base station network are provided in Latvia. The most popular of them are: LatPos and EUPOS-RIGA (Kluga et al., 2013). LatPos is consistent part of state geodetic network, in framework of it, 25 continuously working GNSS base stations are operated at present (see Fig. 2.). In the LatPos system, also 5 Estonian borderline stations un 5 Lithuanian borderline stations are included, in order to ensure homogenous base station network coverage in border areas. Maintenance of LatPos is provided by Latvian Geospatial Informations Agency (LatPos, 2018). In territory of Riga, base station "Ojars" is located.

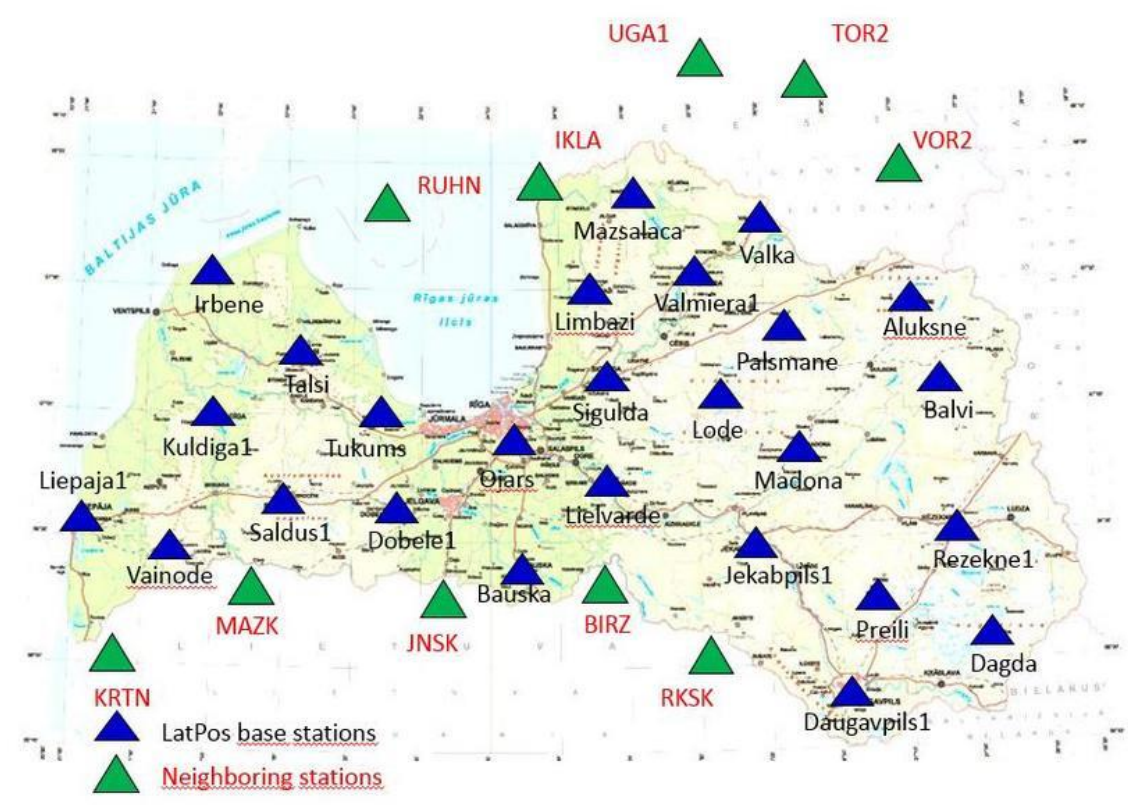

Fig. 2. Continuously Operating Reference Network System LatPos-positions and names of base stations (Dobelis et al., 2017).

EUPOS-RIGA is network of Global Navigation Satellite Systems (GNSS) continuously operating base stations owned by Riga municipality, which calculates GNSS signal corrections for geodetic measurements of high accuracy in Riga City and in surroundings. Network is maintained and served by City Development Department of Riga City Council. Network consists of 5 base stations (see Fig. 3), which are located in center of Riga, Vecmilgravis, Jugla, Salaspils and Jurmala, coverage of network is territory with area more than $2590 \mathrm{~km}^{2}$ (EUPOS-Riga, 2018). At present, EUPOS-RIGA can be considered as consistent part of Riga local geodetic network, which together with LatPos for several years comprised the only legal geodetic base for performance of surveying works. So it is still at present in the territories of Riga, where improvement of the local geodetic network has not taken place. 


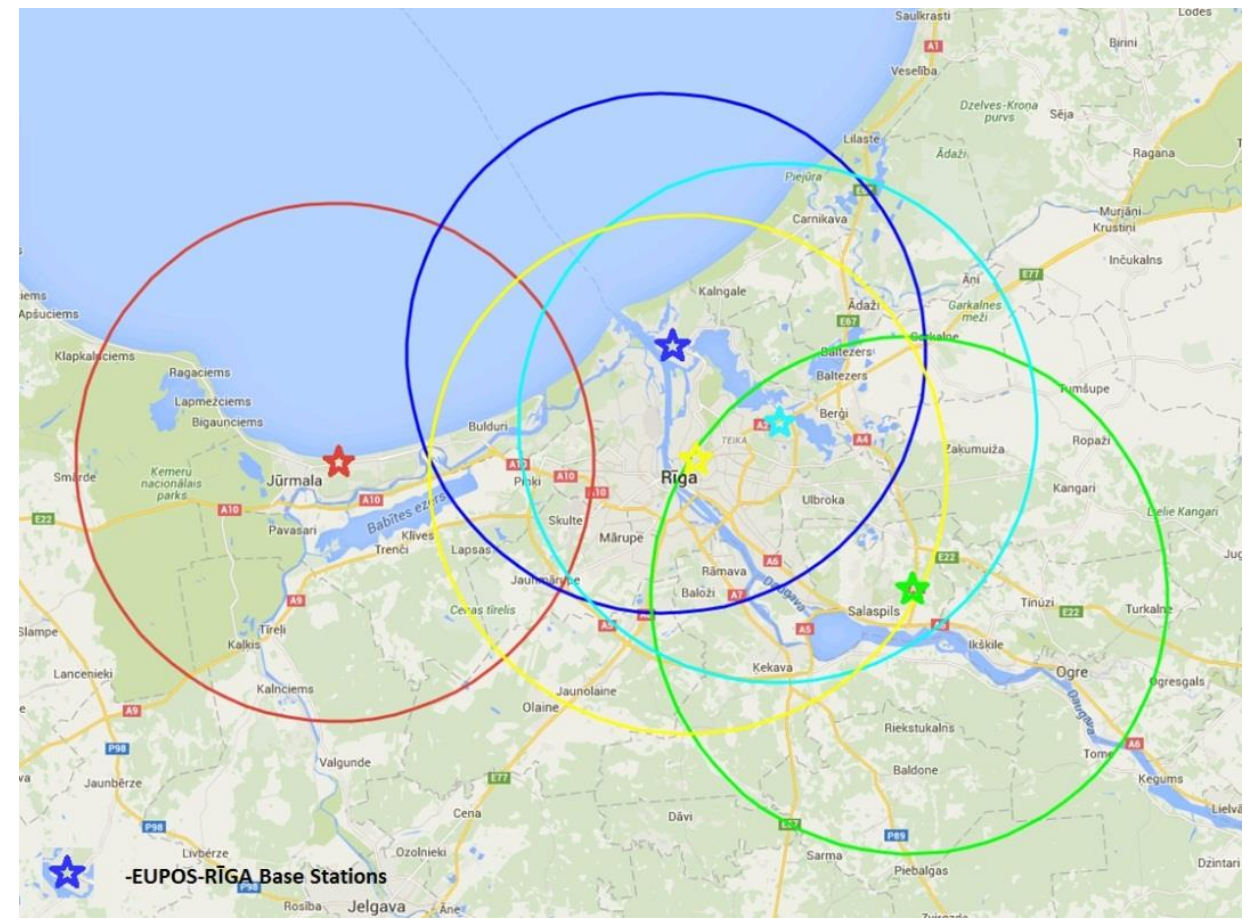

Fig. 3. EUPOS-RIGA - positions of base stations.

At the beginning for the performance of research, 50 points of the local geodetic network in the whole territory of Riga, which can be found in the field according to inspection data of 2013, were selected. However, as GNSS measurements in the field were made, it was found out that a part of polygonometry points is destroyed or it is impossible to make measurements due to the situation in the field. As a result, amount of selected points was supplemented by 11 points. Out of 61 selected polygonometry points GNSS measurements succeeded for 38 points (see Fig. 4.).

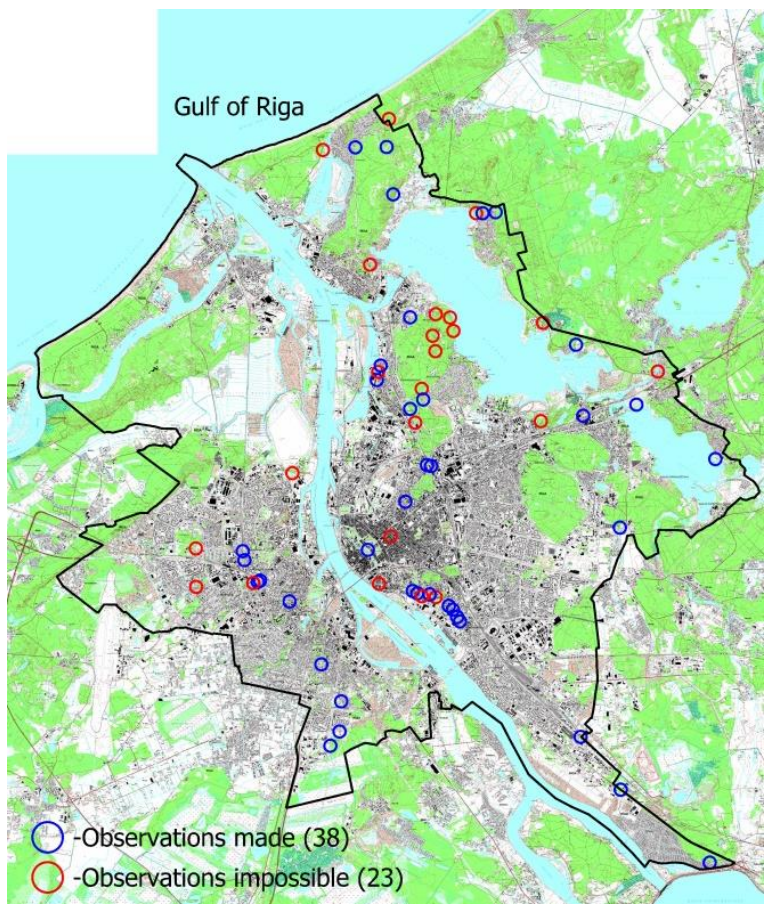

Fig. 4. Local geodetic points selected for the study. 


\section{Discussions and results}

Out of polygonometry points selected for the research, for 45 points coordinates were found in catalogue of 1963 and for the same points coordinates were found in catalogues of eighties. If we compare coordinates determined in these periods, we can find out that for 8 out of 45 points coordinates do not differ. It can be explained with the fact that these polygonometry and triangulation points were used as origins for new polygonometry traverses, and coordinates determined in sixties were assumed as input coordinates.

For polygonometry points, which are included in traverses in both periods and for which coordinates are recalculated differences reach even $0.20 \mathrm{~m}$ (see Fig. 5.).

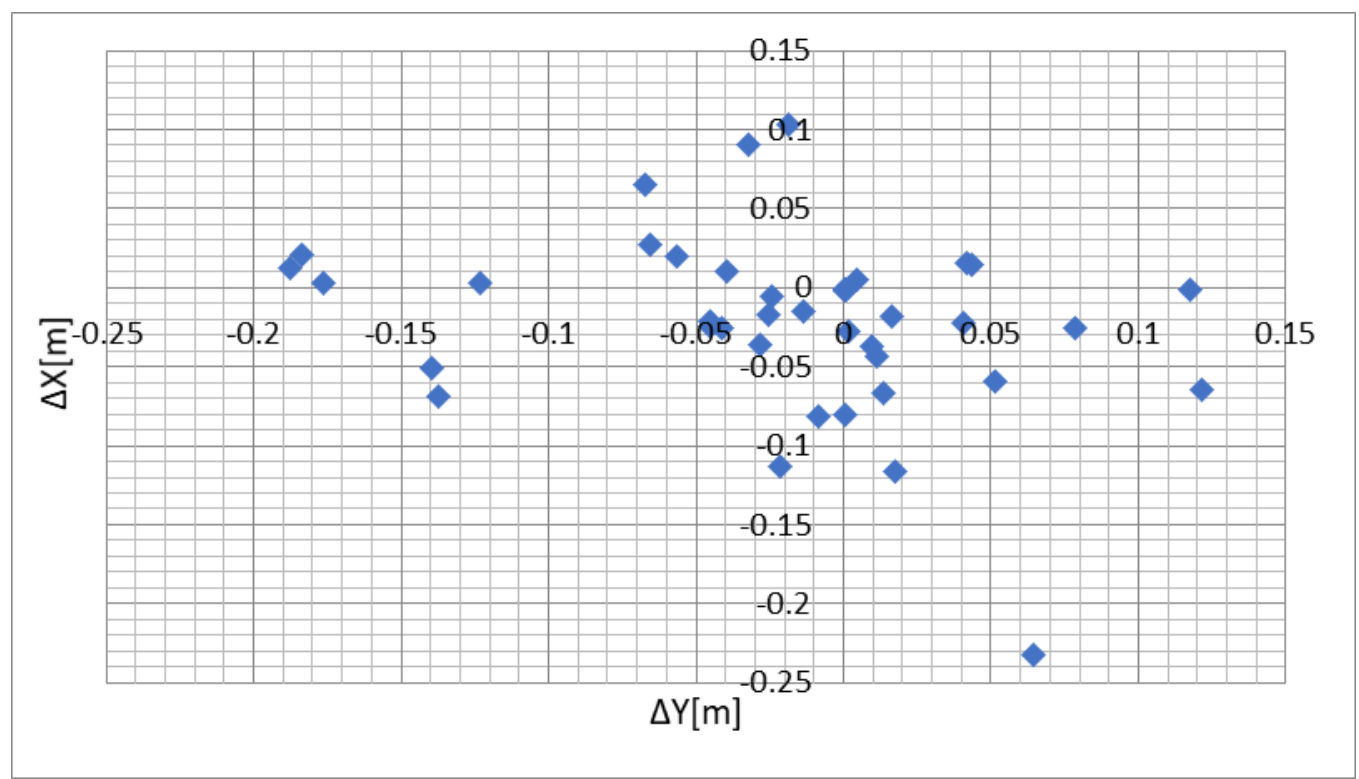

Fig. 5. Differences between coordinates calculated in 60ies and 80ies.

As we can see, the recognized differences of coodinates have not a certain system and they can be explained with accuracy of technical means used for measurements. During the land reform until 2006, when usage of LatPos with real time corrections started widely in Latvia, surveying works of any kind were carried out by use of the existing Riga local geodetic network as geodetic base. Due to this reason, it was interesting to clarify how the coordinates of polygonometry points from catalogues Riga-1, Riga-2, Riga-3 differ from the coordinates determined by use of LatPos in RTK mode (Dobelis, Zvirgzds, 2016). It is found out in the research that differences can reach $0.15 \mathrm{~m}$ (see Fig. 6.).

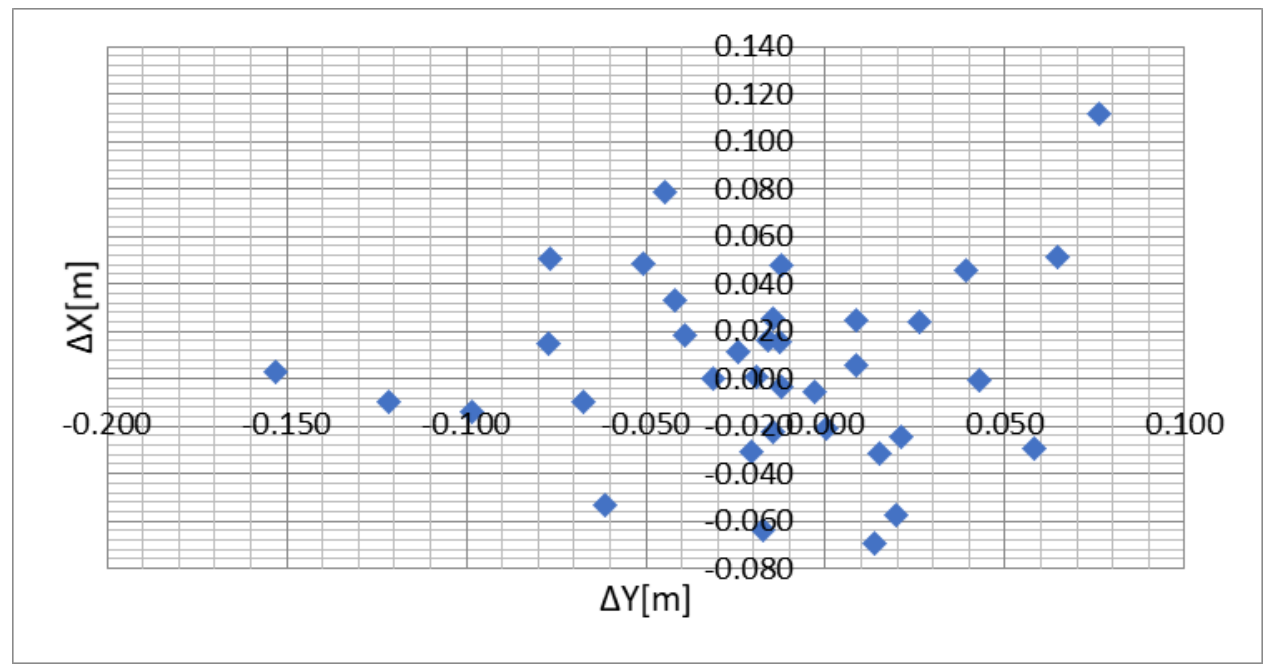

Fig. 6. Differences between coordinates determined in 80-ies and using LatPos. 
Such differences of coordinates influence directly cadastral surveying works, when it is necessary to inspect or restore boundary marks that are surveyed by use of the local geodetic network. Likewise, in the data base of topographic information of high degree of detailing of Riga City, data obtained by measurements using unimproved geodetic network are accumulated for a long time.

Taking into account the fact that in Riga City two GNSS base station networks can be used legally, in the course of the research, it was clarified, what are the differences between coordinates determined in EUPOS-RIGA and LatPos network (see Fig. 7.).

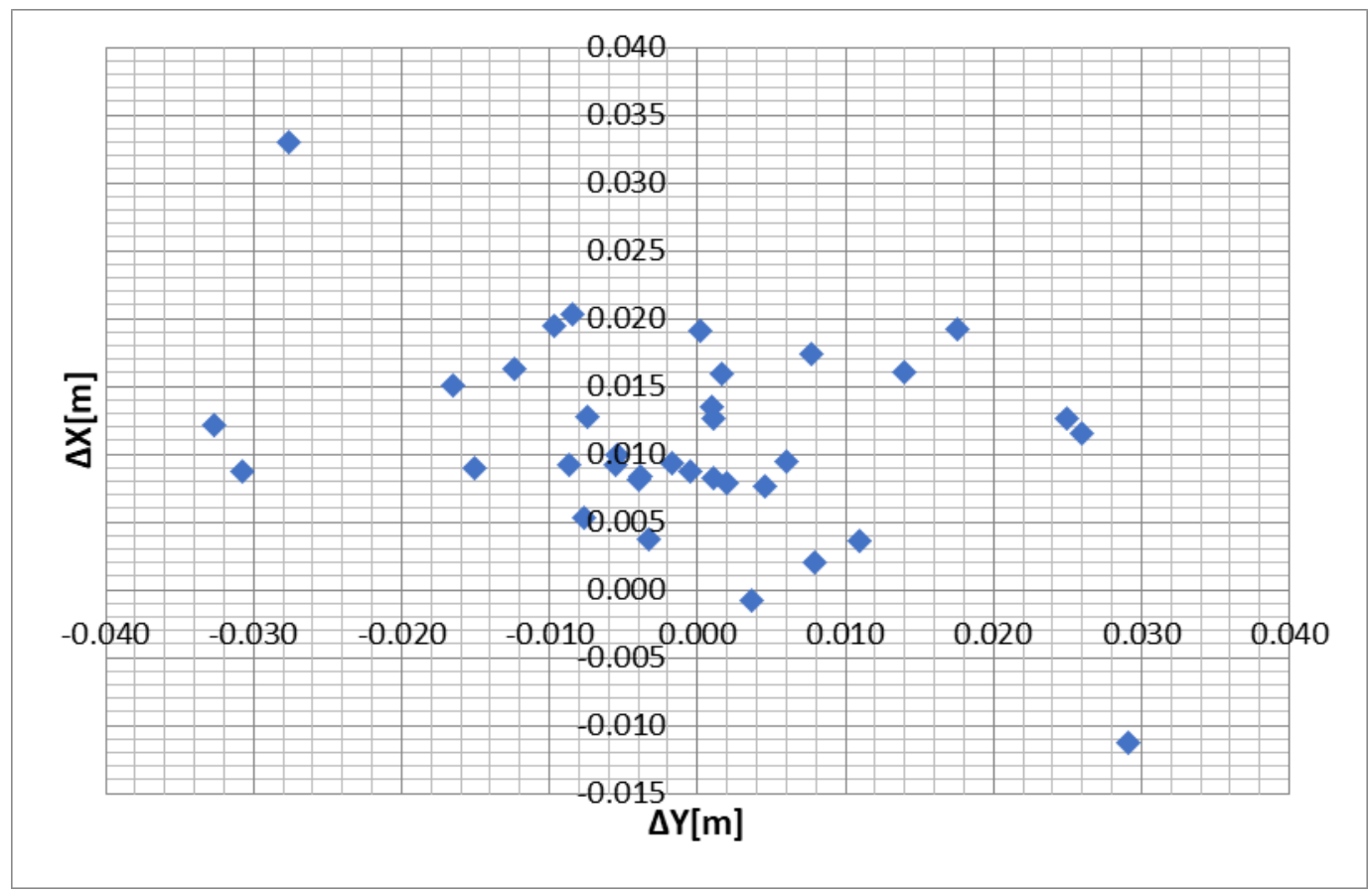

Fig. 7. Differences between coordinates determined using EUPOS-RIGA and LatPos.

In $84 \%$ measurements, differences of coordinates do not reach $0.020 \mathrm{~m}$, which complies with accuracy ensured by both LatPos and EUPOS-RIGA for measurements by use of real time corrections.

\section{Conclusions and proposals}

1. The differences found out in the research between coordinates of poligonometry points determined in sixties and eighties are within limits from 0 to $\pm 188 \mathrm{~mm}$. There cannot be observed equal trends in the recognized differences, therefore we can draw conclusion that they have emerged as a result of some systematic error sources.

2. It is clarified that differences between the coordinates of polygonometry points determined in eighties and coordinates determined by use of LatPos base station network is within limits from 0 to $\pm 154 \mathrm{~mm}$. This testifies that the historical local geodetic network does not comply with requirements of accuracy of regulations of Cabinet of Ministers of 24 July, 2012 No. 497 "Regulations of Local Geodetic Network".

3. For surveying works of any kind in the territory of Riga, both LatPos and EUPOS-RIGA GNSS base station network in RTK mode can be used. They ensure the accuracy requirements defined in normative acts.

4. Usage of Riga local geodetic network points for surveying works is not permitted until they are improved.

5. The created GNSS base station networks play an important role in Riga City local geodetic network. They will serve as the only geodetic base for performing of surveying works in the territories of the city, where the local geodetic network will not be improved. 


\section{Acknowledgements}

The research was supported by the project "Strengthening Research Capacity in the Latvia University of Agriculture" (agreement No 3.2.-10/46; Z6).

Authors are thankful to Riga City Council City Development Department for cooperation and Sergey Plotnikov personally, Jekabs Lielmanis and Karina Akmentina for help with field work during the research.

\section{References}

1. Balodis J., Morozova K., Silabriedis G., Kalinka M., Balodis K., Mitrofanovs I., Baltmane I., Jumare I. (2016) Changing the national height system and GEOID model in LatviaGeodesy and Cartography Volume 42, Issue 1, p. 20-24.

2. Biezak uzdotie jautajumi saistiba ar vietejo geodezisko tiklu. Viewed 15 March, 2018, (http://map.lgia.gov.lv/index.php?lang=0\&cPath=2\&txt_id=119\&ap=1). (In Latvian).

3. Dobelis D., Zvirgzds J. (2016) Network RTK performance analysis: a case study in Latvia. Geodesy and Cartography Volume 42, Issue 3, p. 69-74.

4. Dobelis D., Zvirgzds J., Kaliinka M. (2017) High ionospheric activity effects on LatPos RTK network performance in Latvia. IOP Conference Series: Materials Science and Engineering. Viewed 18 June, 2018, (http://iopscience.iop.org/article/10.1088/1757-899X/251/1/012064/meta).

5. EUPOS-Riga. Homepage of Riga City Council City Development Department. Viewed 18 June, 2018, (http://www.rdpad.lv/geotelpiska-informacija/eupos-riga/). (In Latvian).

6. Kluga A., Kluga J., Bricis A., Mitrofanovs I. (2013) Multiple Frequencies Precise GNSS RTK System Research in Dynamic Mode. IFAC Proceedings Volume 46, Issue 28, p. 95-98.

7. LatPos. Homepage of Latvian Geospatial Information Agency. Viewed 15 June, 2018, (http://map.lgia.gov.lv/index.php?lang=2\&cPath=2\&txt_id=13).

8. Silabriedis G. (2010) Rigas geodeziska vertikala tikla vesture un nakotne. Scientific Journal of Riga $\begin{array}{llllll}\text { Technical } & \text { University } & 2010 . & \text { Viewed } & \text { March, }\end{array}$ (https://ortus.rtu.lv/science/lv/publications/8896/fulltext). (In Latvian).

9. Transformacijas $\quad$ programmas. $\quad$ Viewed $\quad 15 \quad$ March, 2018 , (http://www.vzd.gov.lv/lv/pakalpojumi/profesionaliem/merniekiem/noderigi-materiali/\#Transformacijasprogrammas). (In Latvian).

10. Vieteja geodeziska tikla noteikumi (2012) Regulations of Cabinet of Ministers No 497 24.07.2012. Viewed 25 June, 2018, (https://likumi.lv/doc.php?id=250460). (In Latvian).

11. Vietejais geodeziskais tikls. Homepage of Riga City Council City Development Department. Viewed 25 June, 2018, (http://www.rdpad.lv/geotelpiska-informacija/vietejais-geodeziskais-tikls/). (In Latvian).

Information about authors

Armands Celms, Dr.sc.ing., assoc. professor, Department of Land Management and Geodesy, Faculty of Environment and Civil Engineering, Latvia University of Life Sciences and Technologies. Address: Akademijas Street 19, Jelgava, LV-3001. E-mail: armands.celms@1lu.lv

Velta Parsova, Dr.oec., professor, Department of Land Management and Geodesy, Faculty of Environment and Civil Engineering, Latvia University of Life Sciences and Technologies. Address: Akademijas Street 19, Jelgava, LV-3001. E-mail: velta@parsova.lv

Ilona Reke, PhD student at Department of Land Management and Geodesy, Faculty of Environment and Civil Engineering, Latvia University of Life Sciences and Technologies. Address: Akademijas Street 19, Jelgava, LV3001. E-mail: ilona.reke@ gmail.com

Janis Akmentins, Bc. student at Department of Land Management and Geodesy, Faculty of Environment and Civil Engineering, Latvia University of Life Sciences and Technologies. Address: Akademijas Street 19, Jelgava, LV-3001. E-mail: janis.akmentins@riga.lv 